\title{
REUSE OF MUNICIPAL SOLID WASTE FROM INCINERATED ASH IN THE STABILIZATION OF CLAYEY SOILS
}

Varaprasad B. J. S. ${ }^{1 *}$, Jayaprakash Reddy JOGA ${ }^{2}$, Suryaprakash Reddy JOGA ${ }^{3}$

\begin{abstract}
A useful method for the disposal of waste from an incineration plant is to reuse it for geotechnical and civil engineering applications. The primary objective of this study concerns the reuse of local incinerated ash from municipal solid wastes in soil stabilization. Municipal Solid Waste Incinerated Ash (MSWIA) is blended with soil in various combinations and tested for its Atterberg limits, unconfined compressive strength (UCS), California Bearing Ratio (CBR), and Free Swell Index (FSI). A 1-D Consolidation Test was conducted, and changes in the soil during the test were examined by a scanning electron microscopic (SEM) analysis. The test results showed that there are increments in the UCS and CBR values with the reductions in the FSI, swell pressure, and swell potential of the treated soils.
\end{abstract}

\section{Address}

1 Civil Engineering Department, G Pulla Reddy Engineering College, Kurnool, A.P., INDIA - 518007

2 Dept. of Civil Engineering, JNT University Anantapur, A.P., INDIA $-515002$

3 Dept. of Civil Engineering, S V University, Tirupati, A.P., INDIA517502

* Corresponding author: drbjsvp.ce@gprec.ac.in

Key words

- Solid Waste Incinerated Ash,

- Municipal Waste,

- Hazardous Waste,

- Sustainable Development,

- Soil Stabilization.

\section{INTRODUCTION}

Due to rises in population and industrial growth, the world is currently struggling to dispose of the waste material from municipal solid waste, industrial waste, and construction demolition waste. Every year millions of tons of municipal solid waste are produced. Therefore, the primary concern of many countries is to manage waste wisely. Unrestrained dumping of municipal solid waste has been found on the outskirts of cities and towns. This dumping causes severe problems for the environment, as well as for the health of the public and animals. To manage the massive amount of waste, an incineration method was adopted to treat waste because it reduces the quantity of waste by $60-70 \%$, depending upon the type of waste and type of incineration plant (Williams, P. T, 2005). Incinerating the waste converts organic waste into inorganic residues and ferrous/non-ferrous compounds are formed into silicates (Forteza, R et al., 2004). The residues obtained from the incineration process are of two types: bottom ash and fly ash.

Bottom ash is obtained from the incineration process, which usually contains $25 \%$ of the total incineration mass; the bottom ash obtained is primarily made up of oxides of $\mathrm{Si}, \mathrm{Fe}, \mathrm{Ca}, \mathrm{Al}, \mathrm{Na}$, and $\mathrm{K}$ (Chandler et al., 1994). In general, incineration waste ends up in dumps or landfills or is used as secondary raw material. Many countries facing problems with scarcity of land and strict environmental rules favor the reuse and recycling of waste ash as it contains heavy metals, chlorides, organic pollutants, and salts, which may reduce their application for reuse in many ways (Lam et al., 2010; Chen, X. et al., 2016; Huang, T. et al., 2018; Tang, J. et al., 2018). Due to the presence of heavy metals, chlorides and organic pollutants in waste ash, many countries have classified it as being a harmful substance as it affects humans and the environment and is not recommended for landfilling (Ceglowski et al., 2018). Conceivable methods for its treatment include: (1) thermal treatment, which is not economical and is limited in its large-scale utilization (Liu, Y. et al., 2018); (2) advanced separation, and (3) chemical extraction from secondary pollutants that change the soil conditions (Yan, P. et al., 2016) and stabilization/ solidification (Chen, W. et al., 2017). Soil stabilization is a successful and effective method for handling hazardous waste materials and can be easily applicable (Jafer, H. et al., 2018). Cement is commonly used as a binding material for soil stabilization. However, during the production of cement, high amounts of greenhouse gases are liberated, i.e., 0.6-0.8 tons per one-ton production of cement (Dung, N.T. et al., 2017). Therefore, the replacement of low carbon methods is required for soil stabilization (Saviji, B. et al., 2016). Many studies have re- 


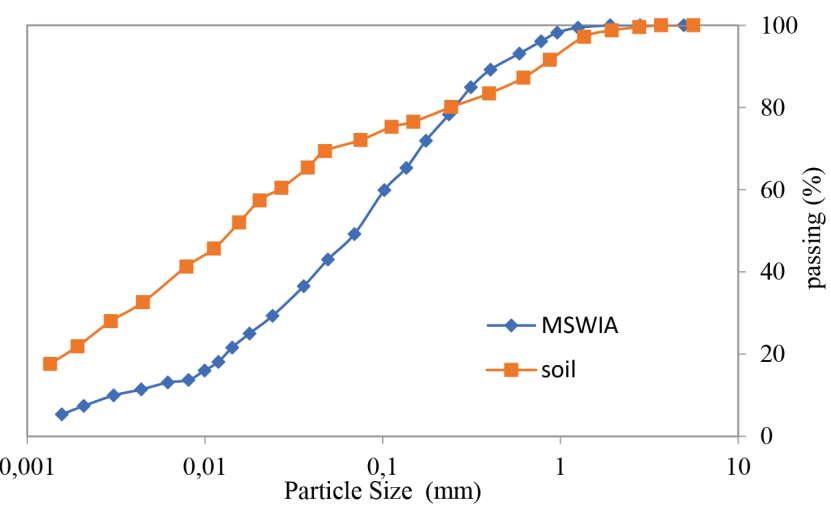

Fig. 1 Particle Size Analysis of Clay and MSWIA

vealed that the application of industrial and agricultural waste, such as mango kernel ash, rice husk ash, waste corn ash, coconut shell ash and ground nutshell ash, helps in increasing the engineering properties of soil, especially undrained shear strength and the compression index (Karthikeyan, D. et al., 2016; Hasan, H. et al., 2016; Vignesh, N. P. et al., 2020; Isha, B.W. et al., 2015; Ayobami, B. et al., 2018; Varaprasad, B. J. S. et al., 2020; James J. 2020). Among the most frequently generated waste is municipal solid waste. From the literature studies it has been observed that Municipal Solid Waste Incineration Ash (MSWIA) can be used as a replacement for sand in concrete with some supplemental materials (Xuan et al. 2018). Le et al., (2017) has stated that municipal solid waste ash helps improve the mechanical properties of soil and can be used as an engineering material to construct pavements and embankments. Many studies have reported that the addition of MSWIA used as a filling material in sub-bases and embankment fills helps increase the geotechnical properties of various soils (Adedokun, T. A. et al., 2013; Le et al., 2017; Lam, C. H. et al., 2010; Lynn, C. J. 2017; Mohamedzein, Y. E. A. 2006; Singh et al., 2019). The reuse of MSWIA as a geotechnical and civil engineering construction material not only helps in the reduction of greenhouse

Tab. 1 Engineering Properties of Soil

\begin{tabular}{lcc}
\hline Parameter & Symbol & Value \\
\hline Specific gravity & $\mathrm{G}$ & 2.64 \\
Natural Water Content & $\mathrm{W}_{\mathrm{n}}$ & $41.56 \%$ \\
$\begin{array}{l}\text { Percentage of fines passing } \\
\text { through ( }>75 \text {-microns) }\end{array}$ & - & $68.33 \%$ \\
pH of soil & - & 7.65 \\
Liquid limit & $\mathrm{W}_{\mathrm{L}}$ & $79 \%$ \\
Plastic limit & $\mathrm{W}_{\mathrm{P}}$ & $32 \%$ \\
Plasticity index & $\mathrm{I}_{\mathrm{p}}$ & $47 \%$ \\
Shrinkage limit & $\mathrm{W}_{\mathrm{S}}$ & $9.8 \%$ \\
Free Swell Index & $\mathrm{FI}$ & $80 \%$ \\
Soil classification & $\mathrm{CH}$ & Clay of High Plasticity \\
Swell pressure & $\mathrm{P}_{\mathrm{S}}$ & $80.83 \mathrm{kPa}$ \\
UCS Test & $\mathrm{q}_{\mathrm{c}}$ & $76.86 \mathrm{kPa}$ \\
CBR Test & & 2.46 \\
Compression index & - & 0.392
\end{tabular}

gases, but also generates energy. It offers an alternative to landfilling and disposal issues.

In this study, Municipal Solid Waste Incinerated Ash (MSWIA) was applied to clayey soils in various combinations of $5,10,15,20$, and $25 \%$ according to the dry weight of the soil. A series of laboratory tests was performed on the treated soil in a geotechnical laboratory to assess the engineering properties of the clayey soils.

\section{MATERIALS AND METHODS}

\subsection{Soil samples}

The soil sample used in this study was collected from the village of Avilala near Tirupati, Andhra Pradesh, India. The soil was collected 2-1.5 m below the existing ground surface to eliminate any loose soil top and vegetation. The soil was collected manually in a disturbed state and oven-dried for 24 hours at $105^{\circ} \mathrm{C}$ to remove any organic content in the soil; it was then pulverized. The engineering properties and chemical composition of the soil are represented in (Tabs. 1-2), and a grain size analysis curve is shown in Fig. 1.

\subsection{Municipal Solid Waste Incinerated Ash (MSWIA)}

The MSWIA was collected in a powder form from the Tirupati Solid Waste Municipal Management plant in Andhra Pradesh, India. The MSWIA was tested for its engineering properties, and the results are shown in Tab. 2. The Atterberg limits indicated that the MSWIA was non-plastic. A grain size analysis test was conducted. The curve is shown in Fig.1. Moreover, a chemical analysis was conducted, and the findings are set out in (Tab. 3).

Tab. 2 Properties of MSWIA

\begin{tabular}{lcc}
\hline Parameter & Symbol & Value \\
\hline Specific gravity & $\mathrm{G}$ & 2.15 \\
$\mathrm{pH}$ & - & 10.3 \\
Natural Water Content & $\mathrm{W}_{\mathrm{n}}$ & $3.6 \%$ \\
Optimum Moisture Content & $\mathrm{OMC}$ & $26 \%$ \\
Maximum Dry Density & $\mathrm{MDD}$ & $14.3 \mathrm{kN} / \mathrm{m}^{3}$ \\
Cohesion & $\mathrm{c}$ & $0 \mathrm{kPa}$ \\
Angle of Internal Friction & $\varphi$ & $35^{\circ}$ \\
Permeability & $\mathrm{k}$ & $1.36^{*} 10-6 \mathrm{~m} / \mathrm{s}$
\end{tabular}

Tab. 3 Chemical Compounds present in Soil and MSWIA

\begin{tabular}{ccc}
\hline Chemical Composition & Soil & MSWI-A \\
\hline $\mathrm{CaO}$ & $3.06 \%$ & $36.6 \%$ \\
$\mathrm{SiO}_{2}$ & $62.32 \%$ & $22.8 \%$ \\
$\mathrm{Al}_{2} \mathrm{O}_{3}$ & $20.8 \%$ & $13.3 \%$ \\
$\mathrm{Fe}_{2} \mathrm{O}_{3}$ & $8.64 \%$ & $6.5 \%$ \\
$\mathrm{MgO}$ & $2.98 \%$ & $2.26 \%$ \\
$\mathrm{Na}_{2} \mathrm{O}$ & $1.65 \%$ & $1.43 \%$ \\
$\mathrm{~K}_{2} \mathrm{O}$ & $0.55 \%$ & $3.38 \%$ \\
Loss of Ignition & - & $14.09 \%$
\end{tabular}




\subsection{Preparation of Samples and Testing Procedure}

Before mixing the MSWIA and soil, both were oven-dried at $105^{\circ} \mathrm{C}$ and sieved through a $0.425 \mathrm{~mm}$ sieve for uniformity of the samples. A standard Proctor test was conducted to determine the Optimum Moisture Content (OMC) and Maximum Dry Density (MDD) of the MSWIA and soil.

The plasticity index $\left(\mathrm{I}_{\mathrm{p}}\right)$ of a treated soil or MSWIA-soil mixture helps to indicate its expansiveness and is used in the soil classification. Different soil types possess various $\left(\mathrm{I}_{\mathrm{p}}\right)$; highly expansive soil has a high $\mathrm{I}_{\mathrm{p}}$. The plasticity index of the soil was determined as per the recommendations of BIS 2720, Part (5).

The standard Procter test was carried out to determine the soil's compaction characteristics such as Maximum Dry Density (MDD) and Optimum Moisture Content (OMC) for various MSWIA contents $(5 \%, 10 \%$, $15 \%, 20 \%$, and $25 \%$ ) according to the dry weight of soil. The dry soil and MSWIA were mixed homogeneously with various water contents, and a standard compaction test was conducted as per BIS 2720, Part (7).

An Unconfined Compressive Strength (UCS) test was performed for both the treated and untreated soil, according to the BIS 2720, Part (10) codal procedure. The soil and MSWIA were mixed homogenously with the optimum water content obtained by a compaction test for a particular mix. The soil was placed in a cylindrical split mould with a $38 \mathrm{~mm}$ diameter and a height of $76 \mathrm{~mm}$ with the same maximum dry density obtained by the specific combination mix in the Proctor test. The sample was extracted from the mould, wrapped in airtight covers, and then cured for various curing days $(7,14,28,60$, and 90 days) at room temperature. For the sake of accuracy, 3 specimens were prepared for each mix combination and curing period and tested at a strain rate of $1.5 \mathrm{~mm} / \mathrm{min}$. After testing for failure, samples were taken for measuring the water content. The Percentage Increase (PI) was calculated from the UCS value using the following relationship:

$$
\mathrm{PI}=\frac{\text { UCS Value }(\text { Treated-Untreated })}{\text { Untreated UCS value of the Soil }}
$$

CBR tests were conducted to evaluate the strength of the base and subgrades for pavements. An un-soaked CBR test was conducted on the treated and untreated clayey soils compacted in three layers in a circular mould with a height of $15.2 \mathrm{~cm}$ and a $12.7 \mathrm{~cm}$ diameter at an MDD in a standard Proctor test for the corresponding mix at different concentrations and different curing days. The prepared samples were cured for different curing periods at room temperature and tested under a strain rate of $1.25 \mathrm{~mm} / \mathrm{min}$ in a CBR testing machine as per BIS codal recommendations. The percentage increase (PI) was calculated from the CBR value using the following relationship:

$$
\mathrm{PI}=\frac{C B R \text { Value }(\text { Treated }- \text { Untreated })}{\text { Untreated CBR value of the Soil }}
$$

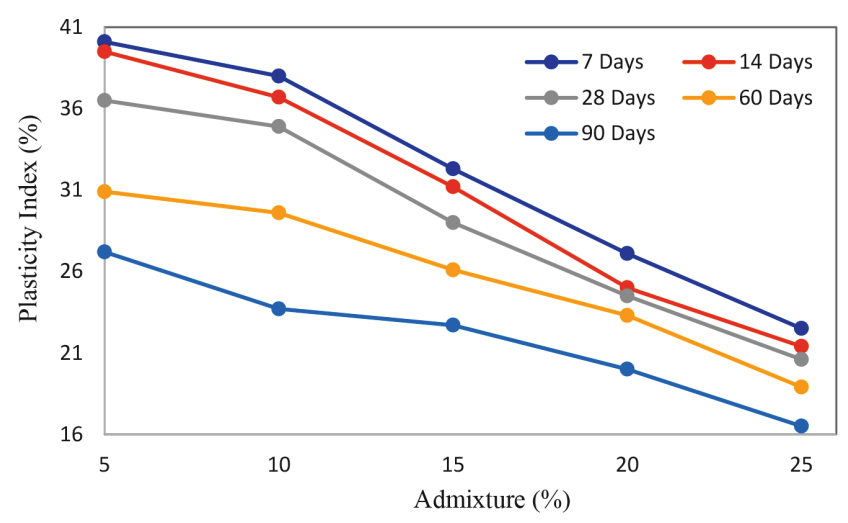

Fig. 2 Plasticity index of treated soil with different curing periods
The Free Swell Index (FSI) is an important indicator for clayey soils, as clays have the potential to change their volume with changes in the moisture content. The FSI is the ratio between the difference in the final volumes of soil in water and kerosene to a final volume of kerosene and is expressed in percentages. Ten (10) grams of the soil sample (passed through a 425-micro sieve) were poured into two cylindrical jars $(100 \mathrm{ml})$; one contained distilled water, and another 10 -gm sample of soil was poured into another jar containing kerosene. The volumes of the two jars were initially measured; after $24 \mathrm{~h}$, the final volume in the two jars was noted to calculate the Free Swell Index value. The FSI was conducted for all the curing periods and all the mixed combinations of the soil and MSWIA.

Air-dried soil was sieved through a $4.75 \mathrm{~mm}$ sieve and then oven-dried. The required weight of the sample was mixed with the required quantity of MSWIA content with a $0 \%$ water content. The blend was compacted in a consolidation ring (height of $20 \mathrm{~mm}$ and diameter of $60 \mathrm{~mm}$ ) with 4 layers each of a $5 \mathrm{~mm}$ thickness compacted at a maximum dry density obtained in a Proctor test for that combination. The initial void ratio was determined, and filter paper and porous stones were placed above and below the consolidated ring. The setup was placed in a consolidation chamber with the load positioned in the centre of the porous stone. Initially, $5 \mathrm{kPa}$ pressure was applied to the sample, and the dial gauge was set at zero. The free swell method was used to determine the swell pressure and swell potential (Seed, H. et al., 1962; Jennings, J. E. 1962). The same setup was used for the compression index with different mixes with varying contents of water and dry densities obtained from the Proctor test as discussed above. The compression index of the soil was determined by the data from a consolidation test.

\section{RESULTS AND DISCUSSIONS}

\subsection{Effect of MSWIA on the Plasticity Index}

Knowledge of the Plastic Index (PI) is of great importance as there is a strong correlation between the PI and the engineering properties of the soil (Show K. Y. et al., 2003). From Fig. 2, it can be observed that as the curing period increased, the plasticity index decreased when compared to the original PI of the soil. There was an excellent reduction in PI of $60 \%$ for $25 \%$ of the MSWIA treated soil. The decrement of PI for the 90-day curing period was 33.6, 42.1, 46.3 , and $51 \%$ respectively for the $5,10,15,20$, and $25 \%$ of MSWIA. The reduction phenomena were due to the decrease in the natural affinity of the MSWIA-treated soils towards the water and helped to cation the exchange between the MSWIA (as it consists of large percentages of $\mathrm{Ca}, \mathrm{Al}$, and $\mathrm{Si}$ ) and the clay particles.

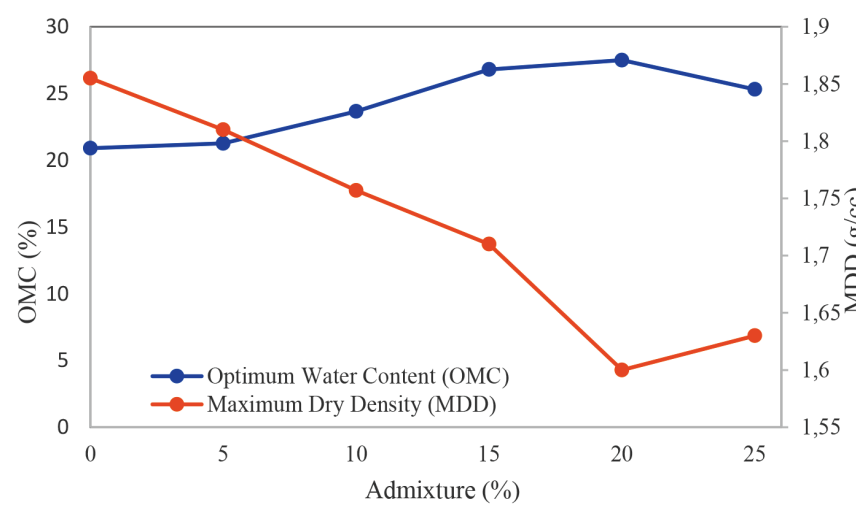

Fig. 3 Compaction characteristics of MSWIA at various percentages 


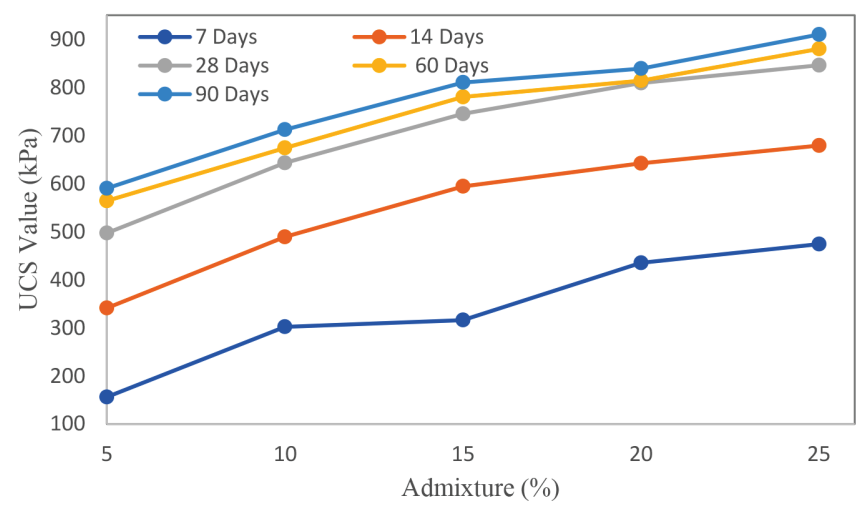

Fig. 4 Change in UCS value with various admixture percentages

\subsection{Effect of MSWIA on Compaction Characteristics}

Fig. 3 shows the compaction characteristics of the MSWIA-treated clayey soil; from Fig.3, it was observed that the addition of MSWIA to the soil decreases its Maximum Dry Density (MDD). The decrease in MDD is observed from $1.855-\mathrm{g} / \mathrm{cc}$ to $1.6-\mathrm{g} / \mathrm{cc}$ for the addition of MSWIA from $0 \%$ to $25 \%$. Further increases in the MSWIA content increased the MDD of the soil. Moreover, the optimum moisture content (OMC) of the soil increased from $20.9 \%$ to $27.5 \%$ for the addition of MSWIA from $0 \%$ to $25 \%$. Further increases in MSWIA decreased the OMC of the soil. The decrement in MDD is due to the low specific gravity of MSWIA when compared to the virgin soil, and the increase in $\mathrm{OMC}$ is due to the absorption of water content by the ash for hydration as it has a pozzolanic property.

\subsection{Effect on Unconfined Compressive Strength (UCS)}

The UCS results revealed that as the concentration of ash increased, the UCS value increased in consideration of the virgin sample. Fig. 4 shows that as the curing days increased, the UCS values increased. From Fig. 4, it is evident that the addition of MSWIA to the soil increases the UCS strength by $80 \%$ for the first 28 -day curing period. This is due to the flocculation of the clay particles and the pozzolanic reaction that occurred between the MSWIA, which allows for a cation exchange between negatively charged clay surfaces with the calcium ions present in the ash. As the MSWIA content increased from 5 to $25 \%$, the percentage increase in strength for 28-days is as follows: $5.4,7.3,8.6,9.5$, and 10 times compared to the virgin sample for a 28 -day curing period. For a 90 -day curing

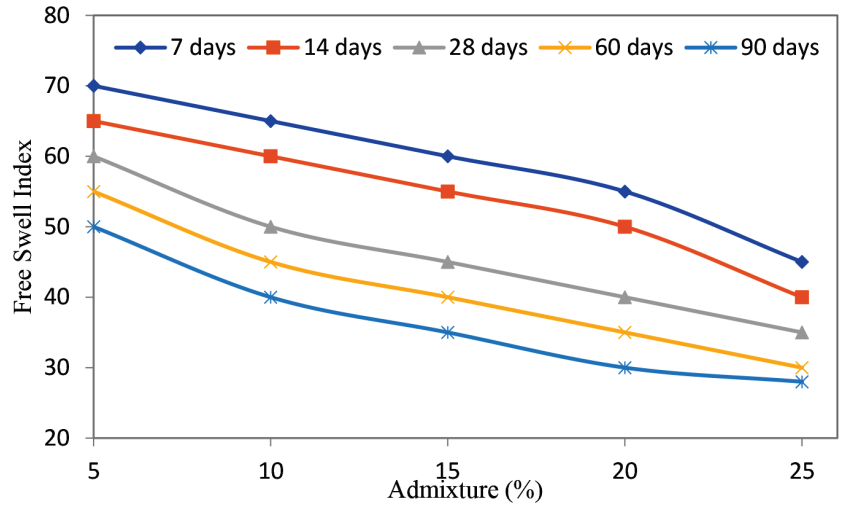

Fig. 6 Variations of FSI with different percentages of MSWIA

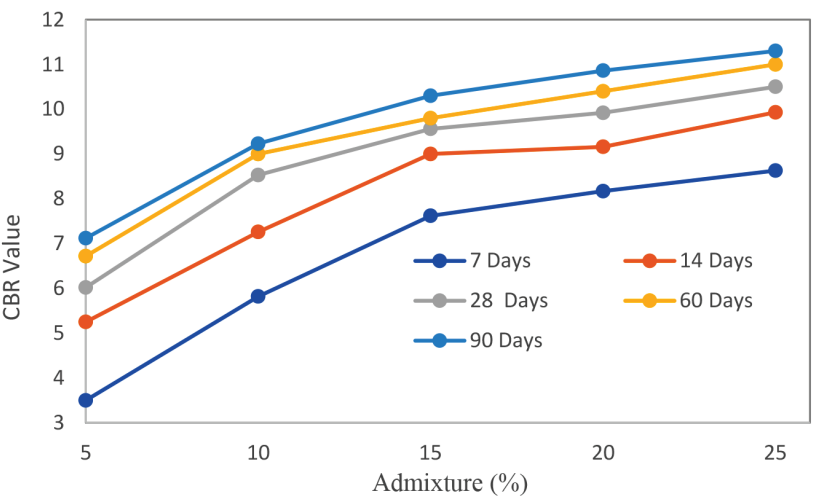

Fig. 5 Variations of CBR values with different percentages of the admixture

period, the overall increase in strength was as follows: $6.6,8.3,9.5$, 9.9, and10.8 times.

\subsection{Effect on the California Bearing Ratio (CBR)}

The mixing of the MSWIA with the soil increased the CBR value by 4.5 times. Fig. 5 shows the variations in the CBR value with the percentages of the admixture, and there is an increment in the CBR value for every percentage of MSWIA content and every curing period. The percentage increment is $3.4,3.9,4.2,4.4$, and 4.5 times with a 28 -day curing period for ash contents of $5 \%, 10 \%, 15 \%, 20 \%$, and $25 \%$ respectively.

The increase in CBR values is due to the chemical compounds present in ash that allows for a pozzolanic reaction, and the calcium ions present in the ash that are attracted by the negative charges present in the clay particles help in the cation exchange mechanism. As Fig. 5 shows, the increase in the CBR value is rapid for the first 28 days, i.e., approximately 4 times compared to the virgin sample. This is because the calcium ions present in the soil participate in an ion exchange process with the clay particles

\subsection{Effect on swelling characteristics}

As Fig. 6 shows, there is a decrease in the FSI of the treated soil as the MSWIA increases; the decrement is nearly $60 \%$ on $25 \%$ of the MSWIA-treated soil for a 7-day curing period. A further reduction in the treated samples was observed as the curing period increased, which is due to the non-plastic properties of the incin-

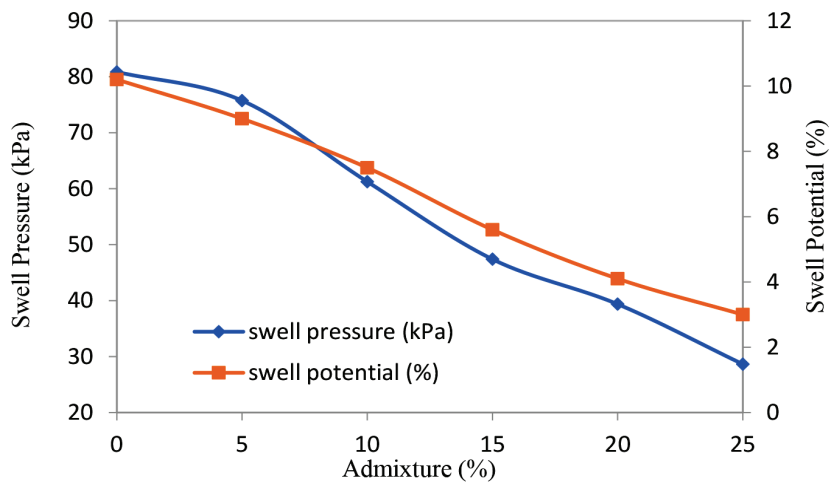

Fig. 7 Variations of swell pressure and swell potential with varying proportions of MSWIA 
eration ash. The presence of the pozzolanic compounds in the ash helps in the flocculation of the clay particles and helps in the ion exchange process, which decreases swelling. Fig. 7 clearly shows that the potential swelling pressure decreases with the addition of MSWIA to the soil; with lower ash contents the decrement in the potential swell and pressure is considerably lower, and as the ash content increases up to $25 \%$, the reduction in the swell pressure and swell potential is up to $65 \%$ and $70 \%$ compared to the virgin samples. Hence the decline in the swelling characteristics is due to the increase in MSWIA. As MSWIA is a non-plastic material, it decreases the affinity to take the water from clay and reduces the inter-repulsive forces in between the clay (Phani Kumar, B. R. et al., 2004; Cokca, E. 2001).

\subsection{Scanning Electron Microscope (SEM)}

To explain the effect of morphology on the incinerated ash from mixed samples of municipal solid waste, a scanning electronic microscopy (SEM) analysis was conducted. Fig. 8 shows that the treated soil had 7, 14, and 28-day curing periods. Fig. 8(a) shows the 7 -day cured sample and reveals that cementitious compounds are formed as white lumps between the soil particles. Fig. 8(b) shows the 14-day cured sample, which indicates the filling of most of the void spaces present in the soil structure, while the 28-day cured specimen shown in Fig. 8(c) reveals a new compound blanketed in the form of coatings on the surface of the clay particles. The contributions for improving the UCS value are due to the denser fabric structure and cementitious bonds between the clay and MSWIA (Cokca, E. 2001; Phetchuay, C. et al., 2014; Suksiripattanaponga, C. et al., 2017). Therefore, there is proof that the addition of MSWIA to clay soil alters its fabric structure by aggregation and by the formation of cementitious compounds.

\section{CONCLUSIONS}

Based on the experimental data concerning the performance of MSWIA on the strength properties and changes in the swelling characteristics of clayey soils, the following conclusions can be drawn:

- The maximum dry density (MDD) of the soil decreased with the increase in the MSWIA content up to $25 \%$; afterwards, the addition of MSWIA to the soil decreases the MDD. The optimum moisture content increases as the ash content increased up to $25 \%$; afterwards, the increase in the MSWIA content decreased the OMC of the MSWIA-treated soil.

- The UCS of the stabilized clayey soil increased with the increase in the MSWIA content up to $25 \%$ and then decreased with the increase in the ash content. Eighty percent $(80 \%)$ increases in the UCS value were observed during the 28-day curing period; afterwards, the increment was minimal up to 90 days.

- The CBR value increased with the increase in MSWIA content with increased curing days. A 4.5 times increase in the strength value of the CBR was observed for $25 \%$ of the MSWIA compared to the virgin sample. It can therefore be used as a sub-base material in roads and pavements.

- The plasticity index $\left(\mathrm{I}_{\mathrm{p}}\right)$ of the soil decreased with the addition of the MSWIA content, which resulted in a decrease in the swell characteristics of the MSWIA-treated soil.

- The addition of MSWIA to soils decreased the FSI by $60 \%$ and the Swell Potential and Swell Pressure by $65 \%$ and $70 \%$. The decrement in swelling is because of the non-plastic nature and cementitious property of MSWIA, which allows the clay to change its affinity towards water.

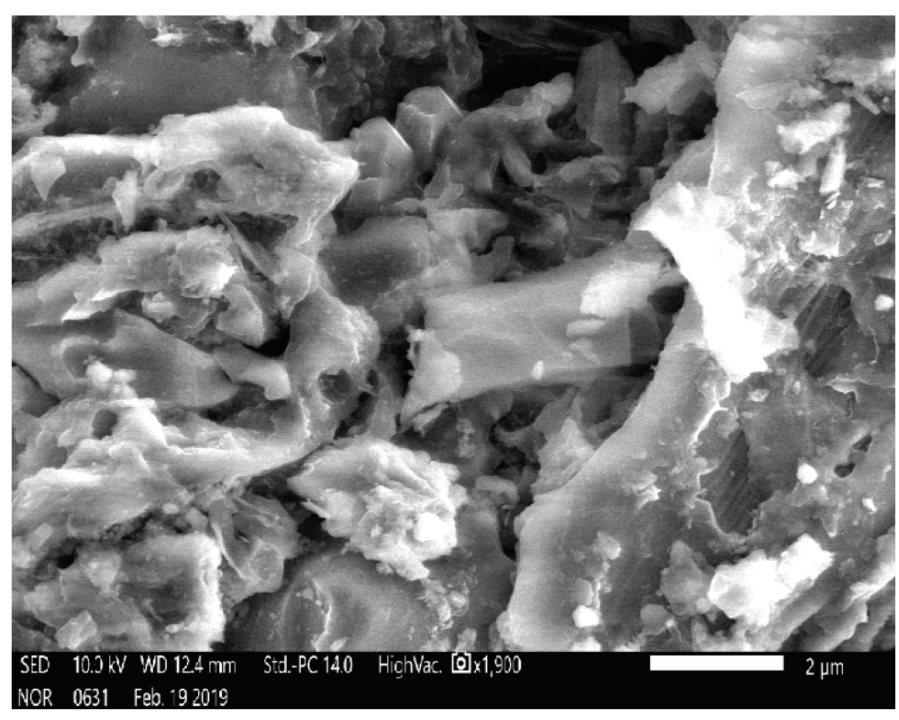

(a)

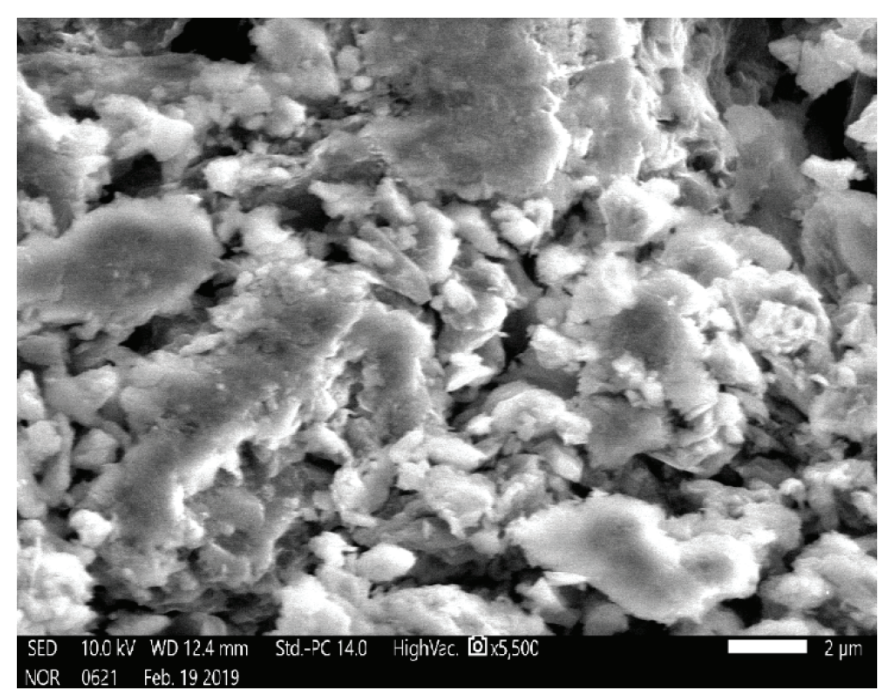

(b)

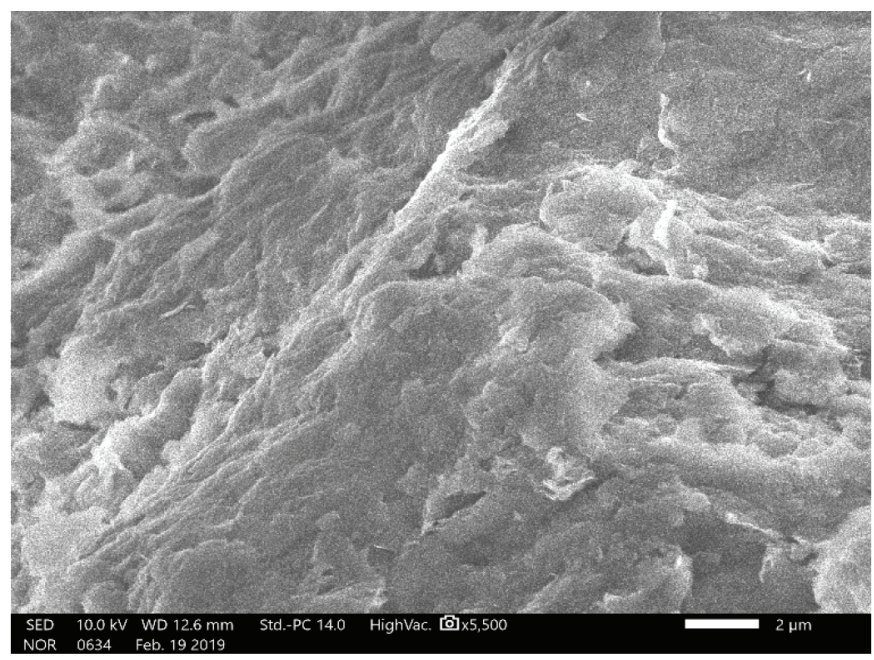

(c)

Fig. 8 SEM morphology of MSWIA-treated the soil for different curing periods: (a) 7-day curing period; (b) 28-day curing period; (c) 90-day curing period 


\section{ACKNOWLEDGEMENT}

The authors would like to thank the Geotechnical Engineering Laboratory and supporting staff, and the Department of Civil Engineering, G. Pulla Reddy Engineering College (Autonomous), Kurnool, for their support during the experimentation.

\section{REFERENCES}

Adedokun, T. A. - Abdulfatah, A. Y. - Kiru, S. G. (2013) Geotechnical evaluation of municipal solid waste as an alternative material for land filling. Int J Emerg Technol Eng, 2250-2459.

Ayobami, B. U. S. A. R. I. - Oyedepo, J. - Ofuyatan, O. - Nurain, S. - Ajayi, S. - Oti, M. N. (2018) Sustainability in Road Construction: Using Bamboo Straw Ash to Improve the Index Properties of Lateritic Soil. European Journal of Sustainable Development, 7(1), 89-89.

BIS. (1980) IS 2720 Methods of Test for Soils: Part 7- Methods of Test for Soils: Part 7 Determination of Water Content-Dry Density Relation Using Standard Compaction. India.

BIS. (1985) IS 2720 Methods of Test for Soils: Part 5- Methods of Test for Soils: Part 7 Determination of Atterberg Limits. India.

BIS. (1991) IS 2720 Methods of Test for Soils: Part 10 - Determination of Unconfined Compressive Strength. India.

Ceglowski, M. - Gierczyk, B. - Frankowski, M. - Popenda, L. (2018) A new low-cost polymeric adsorbents with polyamine chelating groups for efficient removal of heavy metal ions from water solutions. Reactive and Functional Polymers, vol. 131, pp. 64-74.

Chandler, A. J. - Eighmy, T. T. - Hartlen, J., Hjelmar, O. - Kosson, D. S. - Sawell, S. E.- Vehlow, J. (1994) An international perspective on characterization and management of residues from municipal solid waste incineration. Summary Report of the IAWG, c/o Compass Environmental Inc. 2253.

Chen, W. - Kirkelund, G. M. - Jensen, P. E. - Ottosen, L. M. (2017) Comparison of different MSWI fly ash treatment processes on the thermal behavior of $\mathrm{As}, \mathrm{Cr}, \mathrm{Pb}$ and $\mathrm{Zn}$ in the ash. Waste management, vol. 68, pp. 240-251.

Chen, X. - Bi, Y. - Zhang, H. - Wang, J. (2016) Chlorides removal and control through water-washing process on MSWI fly ash. Procedia Environmental Sciences, vol. 31, pp. 560-566.

Cokca, E. (2001) Use of class c fly ashes for the stabilization of an expansive soil. Journal of Geotechnical and Geoenvironmental Engineering, vol. 127(7), pp. 568-573.

Dung, N. T. - Unluer, C. (2017) Carbonated MgO concrete with improved performance: the influence of temperature and hydration agent on hydration, carbonation and strength gain. Cement and Concrete Composites, vol. 82, pp. 152-164.

Forteza, R. - Far, M. - Segu, C. - Cerda, V. (2004) Characterization of bottom ash in municipal solid waste incinerators for its use in road base. Waste management, vol. 24(9), pp. 899-909.

Hasan, H. - Dang, L. - Khabbaz, H. - Fatahi, B. - Terzaghi, S. (2016) Remediation of expansive soils using agricultural waste bagasse ash. Procedia engineering, 143, 1368-1375.
Huang, T. - Liu, L. - Zhou, L. - Yang, K. (2018) Operating optimization for the heavy metal removal from the municipal solid waste incineration fly ashes in the three-dimensional electrokinetics. Chemosphere, vol. 204, pp. 294-302.

Isah, B. W. - Sharmila, S. M. R. (2015) Soil Stabilization Using Calcium Carbide Residue and Coconut Shell Ash. J. Basic Appl. Eng. Res, 2(12), 1039-1044.

Jafer, H. M. - Atherton, W. - Sadique, M. - Ruddock, F. - Loffill, E. (2018) Development of a new ternary blended cementitious binder produced from waste materials for use in soft soil stabilization. Journal of cleaner production, vol. 172, pp. 516-528.

James, J. (2020). A Micro-Level Investigation of Optimum Lime-Content Stabilized Expansive Soil Amended with Organic Coconut Shell Powder. Slovak Journal of Civil Engineering, 28(1), 1-10.

Jennings, J. E. (1962) The heaving of buildings and the associated economic consequences, with particular reference to the Orange Free State goldfields. Civil Engineering Siviele Ingenieurswese, 1962(v4i11), pp. 221-248.

Karthikeyan, D. - Ravichandran, P.T. - Reddy, J.J.P. (2016) Study on strength characteristics of soil with agro waste. Indian Journal of Science and Technology, Vol. 9, No. 33.

Lam, C. H. - Ip, A. W. - Barford, J. P. - McKay, G. (2010) Use of incineration MSW ash: a review. Sustainability, vol. 2(7), pp. 1943-1968.

Le, N. H. - Abriak, N. E. - Binetruy, C. - Benzerzour, M. - Nguyen, S. T. (2017) Mechanical behavior of municipal solid waste incinerator bottom ash: Results from triaxial tests. Waste Management, 65, 37-46.

Liu, Y. - Sidhu, K. S. - Chen, Z. - Yang, E. H. (2018) Alkali-treated incineration bottom ash as supplementary cementitious materials. Construction and Building Materials, vol. 179, pp. 371-378.

Lynn, C. J. - Ghataora, G. S. - OBE, R. K. D. (2017) Municipal incinerated bottom ash (MIBA) characteristics and potential for use in road pavements. International Journal of Pavement Research and Technology, 10(2), 185-201.

Mohamedzein, Y. E. A. - Al-Aghbari, M. Y. - Taha, R. A. (2006) Stabilization of desert sands using municipal solid waste incinerator ash. Geotechnical \& Geological Engineering, 24(6), 17671780.

Phani Kumar, B. R. - Sharma, R. S. (2004) Effect of fly ash on engineering properties of expansive soils. Journal of Geotechnical and Geoenvironmental Engineering, vol. 130(7), pp. 764-767.

Phetchuay, C. - Horpibulsuk, S. - Suksiripattanapong, C. Chinkulkijniwat, A. - Arulrajah, A. - Disfani, M. M. (2014) 
Calcium carbide residue: Alkaline activator for clay-fly ash geopolymer. Construction and Building Materials, vol. 69, pp. 285294.

Šavija, B. - Luković, M. (2016) Carbonation of cement paste: understanding, challenges, and opportunities. Construction and Building Materials, vol. 117, pp. 285-301.

Seed, H. B. - Lundgren, R. (1962) Prediction of swelling potential for compacted clays. Journal of the soil mechanics and foundations division, vol. 88(3), pp. 53-88.

Show, K. Y. - Tay, J. H. - Goh, A. T. (2003) Reuse of incinerator fly ash in soft soil stabilization. Journal of materials in civil engineering, vol. 15(4), pp. 335-343.

Singh, D. - Kumar, T. - James, B. E. - Hanifa, M. (2019) Utilization of MSWI Ash for Geotechnical Applications: A Review. In: Environmental Geotechnology (pp. 229-236). Springer, Singapore.

Suksiripattanapong, C. - Kua, T. A. - Arulrajah, A. - Maghool, F. - \& Horpibulsuk, S. (2017) Strength and microstructure properties of spent coffee grounds stabilized with rice husk ash and slag geopolymers. Construction and Building Materials, vol. 146, pp. 312-320.

Tang, J. - Ylmén, R. - Petranikova, M. - Ekberg, C. - Steenari, B. M. (2018) Comparative study of the application of traditional and novel extractants for the separation of metals from MSWI fly ash leachates. Journal of cleaner production, vol. 172, pp. 143154.

Varaprasad, B. J. S. - Reddy, J. J. - Reddy, J. S. (2020) Remediation of expansive soils using mango kernel ash and calcium carbide residue. International Journal of Environment and Waste Management, 25(2), 220-230.

Vignesh, N. P. - Mahendran, K. - Arunachelam, N. (2020) Effects of Industrial and Agricultural Wastes on Mud Blocks Using Geopolymer. Advances in Civil Engineering, 2020.

Williams, P. T. (2005) Waste treatment and disposal. John Wiley \& Sons, London, England.

Yan, P. - Ye, M. - Sun, S. - Xiao, X. - Dai, W. - Zhang, N. (2016) Removal performances and mechanisms of action towards ethylenediaminetetraacetic acid nickel (II) salt by dithiocarbamate compounds having different carbon chain lengths. Journal of Cleaner Production, vol. 122, pp. 308-314. 